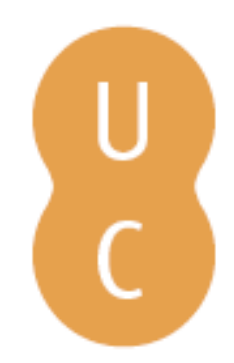

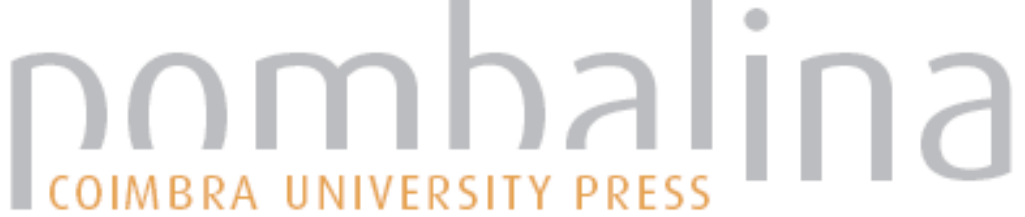

\section{Consideration of an empirical model for wildland firefighter safety zones}

\author{
Autor(es): $\quad$ Butler, B.
}

Publicado por: Imprensa da Universidade de Coimbra

URL

persistente: URI:http://hdl.handle.net/10316.2/34306

DOI: $\quad$ DOI:http://dx.doi.org/10.14195/978-989-26-0884-6_147

Accessed : $\quad$ 26-Apr-2023 13:55:05

A navegação consulta e descarregamento dos títulos inseridos nas Bibliotecas Digitais UC Digitalis, UC Pombalina e UC Impactum, pressupõem a aceitação plena e sem reservas dos Termos e Condições de Uso destas Bibliotecas Digitais, disponíveis em https://digitalis.uc.pt/pt-pt/termos.

Conforme exposto nos referidos Termos e Condições de Uso, o descarregamento de títulos de acesso restrito requer uma licença válida de autorização devendo o utilizador aceder ao(s) documento(s) a partir de um endereço de IP da instituição detentora da supramencionada licença.

Ao utilizador é apenas permitido o descarregamento para uso pessoal, pelo que o emprego do(s) título(s) descarregado(s) para outro fim, designadamente comercial, carece de autorização do respetivo autor ou editor da obra.

Na medida em que todas as obras da UC Digitalis se encontram protegidas pelo Código do Direito de Autor e Direitos Conexos e demais legislação aplicável, toda a cópia, parcial ou total, deste documento, nos casos em que é legalmente admitida, deverá conter ou fazer-se acompanhar por este aviso. 


\section{ADVANCES IN}

Forest Fire

\section{RESEARCH}

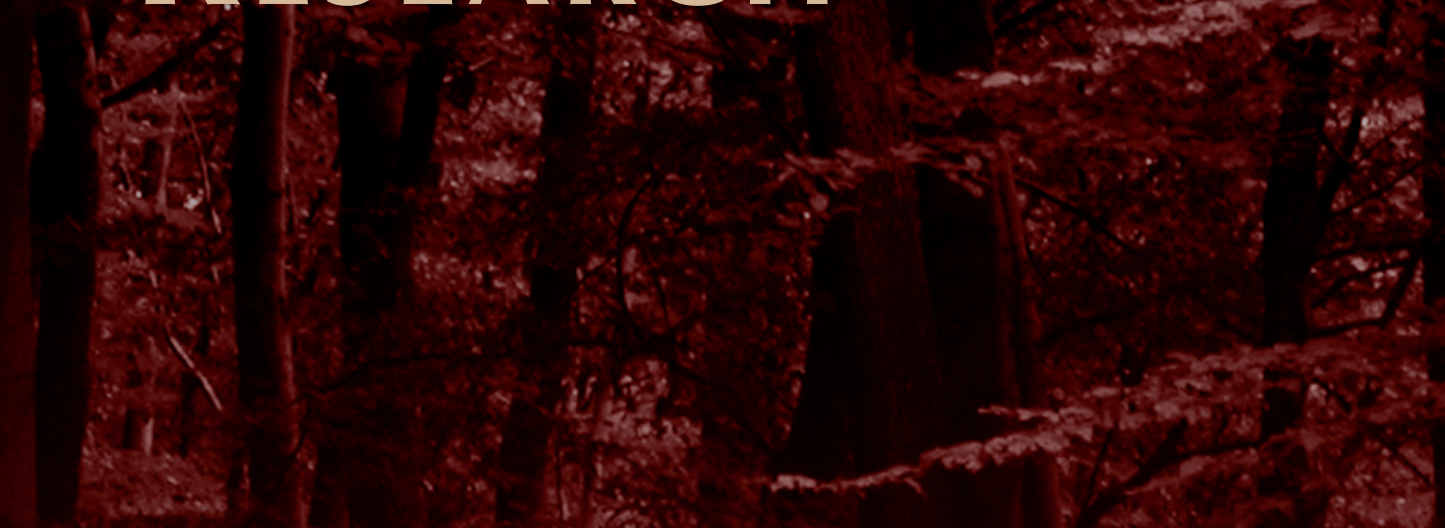

\section{DOMINGOS XAVIER VIEGAS}

\section{EDITOR}




\title{
Consideration of an Empirical Model for Wildland Firefighter Safety Zones
}

\author{
B. Butler
}

\author{
USDA Forest Service, Rocky Mountain Research Station, Fire Sciences Laboratory 5775 W US
}

Highway 10 Missoula MT 59808, USA bwbutler@fs.fed.us t:406 3294801

\begin{abstract}
The term safety zone was first introduced into the official literature in 1957 in the aftermath of the Inaja fire that killed 11 firefighters. Since then identification of safety zones has been a primary duty of all wildland firefighters. Unfortunately, information regarding what constitutes an adequate safety zone is not well defined. Measurements of energy release from wildland fires have been used to develop an empirically based safety zone guideline. The proposed model is compared against past fire entrapments in North America. The comparison indicates that the empirical model does provide an extra margin of safety over most entrapments that are associated with injury or fatalities but it seems to underpredict the separation distance needed to meet the full definition of a safety zone.
\end{abstract}

Keywords: Fire behavior, prescribed fire, firefighter safety

\section{Introduction}

Wildland firefighting by its nature is inherently dangerous. 699 wildland firefighters died in fire related accidents between 1910 and 1996 in the United States, 384 of those were directly related to fire entrapments (National Wildfire Coodinating Group 1997). Wildland firefighters must consider the risks to themselves and others when approaching, suppressing, and managing wildland fire and take action to minimize those risks (National Wildfire Coodinating Group 2004). The identification of suitable safety zones for firefighters during daily fire management operations is perhaps one of the most critical decisions made on wildland fires.

All wildland firefighters in the United States are required to identify safety zones when working on or near fire. Until1998 the regulatory agencies responsible for wildland fire management in North America did not provide any quantitative information about safety zone characteristics other than that proposed by Butler and Cohen (1998) which was subsequently included in the Fireline Handbook (National Wildfire Coodinating Group 2004). The safety zone guidelines are based on the assumption that the fire and safety zone were located on flat terrain. The minimum safe distance for a firefighter to be from a flame was calculated as that corresponding to a radiant incident energy flux level of 7.0 $\mathrm{kW}-\mathrm{m}-2$. This was determined to be the level at which exposed human skin will develop a 2 nd degree burn in less than 90 seconds. An approximate correlation was derived from this model that indicated a minimum separation between the firefighter and fire should be equal to four times the flame height. For a circular safety zone this would be equal to the safety zone radius. When fires are burning on flat terrain, convective energy transfer is primarily upward in the plume while radiant energy transfer occurs out ahead of the fire front. Current firefighter safety guidelines are based on the assumption that radiant energy transfer is the dominant energy transfer mode. Measurements have verified the accuracy of this assumption but have also indicated that when fires are burning on slopes or under the influence of wind convective energy transfer ahead of the fire front can be significant. Intuition, professional observations, and experimental measurements indicate that when fires are located on slopes or ridges or are burning with a strong wind convective energy transfer may reach distances two to four or more flame lengths ahead of the fire front. This implies that the current safety zone guidelines may be invalid in some situations. It is also clear from site visits to designated safety zones on 
numerous wildland fire incidents that considerable ambiguity exists regarding identification or creation of true 'safety zones,' versus 'deployment zones.'

Measurements of energy release from fires have been gathered from a range of ecosystem and vegetation types. The data were used to calculate the distribution of energy in and around those flames (Frankman et al. 2012a). Measurements and analysis of fires and safety zones on flat terrain showed that the current safety zone guidelines were adequate with the assumption that both the fire and safety zone were on flat terrain. Additional guidelines were developed that related safety zone size in acres to flame height in feet and to account for changes in safety zone size necessary to accommodate equipment and multiple personnel. When the influence of slope on fire intensity and spread is considered, the current safety zone guidelines that were designed for flat terrain and low wind clearly become inadequate. With this need in mind efforts have focused on measuring energy release from fires burning in natural conditions. While a very small subset of the data collected corresponds to fire on slopes, the data suggest a potential safety zone rule that encompasses all terrain and weather conditions as a function of vegetation type. These measurements are analysed to propose an empirically based firefighter safety zone rule.

\section{Methods - Energy Measurements}

Definition of a firefighter safety zone requires determination of the fire energy source strength; calculation of burn injury as a function of heating magnitude and duration; and estimation of safe separation distance (SSD) from the fire to prevent injury.

Energy is transported from wildland fires primarily by two heating modes: 1) radiative energy transport (Albini 1986; Viskanta 2008) and 2) convective energy transport (Yedinak et al. 2006; Anderson et al. 2010). Some cases exist where radiation dominates fire energy transport, for example a fire spreading through grass in the absence of wind would seem to be driven by radiant heating ahead of the flaming front, or a large crown fire with minimal ambient wind would also be characterized by primarily radiant heating although in both cases it is difficult to separate the radiant heating from the advective influence of lofting and ignition from burning embers that act as ignition pilot sources (Albini 1986). Logically, convective heating should also play a critical role in fire spread, for example a fire burning through grass in the presence of a very strong ambient wind where the wind causes the flames to reach ahead of the burning front preheating vegetation far in advance of the fire through direct contact between the flames and unignited fuels. In this case convective energy transport would dominate energy transport and fire spread. Recent measurements support this (Yedinak et al. 2010; Frankman et al. 2012a).

Safety zone studies have assumed that radiative heating is the primary heating mode (Butler and Cohen 1998; Zarate et al. 2008; Rossi et al. 2011). Various methods have been used to measure radiant energy release from wildland flames. Butler (1993) describes a simple radiometer. Packham and Pompe (1971) measured radiative heat flux from a fire in Australian forest lands. Heating reached $100 \mathrm{~kW} \mathrm{~m}-$ 2 when the flame was adjacent to the sensor and $57 \mathrm{~kW} \mathrm{~m}-2$ when the sensor was a distance $7.6 \mathrm{~m}$ from the flame (King 1961), no description of flame dimensions were provided. Butler et al. (2004) presented temporally resolved irradiance measurements in a boreal forest crown fire burning primarily in jack pine (Pinus banksiana) with an understory of black spruce (Picea mariana). Irradiance values reached $290 \mathrm{~kW} \mathrm{~m}-2$, flames were $25 \mathrm{~m}$ tall, and fire spread rates were nominally $1 \mathrm{~m} \mathrm{~s}-1$. Morandini et al. (2006) measured time-resolved irradiance values from flames burning in $2.5 \mathrm{~m}$ tall Mediterranean shrubs (Olea europea, Quercus ilex, arbustus unedo, Cistus Monspeliensis and Cytisus triflorus). Radiative heat fluxes peaked at $1,2.2$ and $7.8 \mathrm{~kW} \mathrm{~m}$-2for distances to flames of 15,10 and $5 \mathrm{~m}$ respectively. Silvani and Morandini (2009) measured time-resolved radiative and total heat fluxes incident on the sensor in fires burning in pine needles and oak branches. For the burn conducted on a slope of $36 \%$ with flame heights of $5.6 \mathrm{~m}$ the peak radiative and total heating at the sensor were 51 $\mathrm{kW} \mathrm{m-2} \mathrm{and} 112 \mathrm{~kW} \mathrm{m-2} \mathrm{respectively,} \mathrm{implying} \mathrm{that} \mathrm{convective} \mathrm{heating} \mathrm{was} \mathrm{nominally} \mathrm{of} \mathrm{the} \mathrm{order}$ 
of the radiative heating. Frankman et al. (2012a) report measurements from fires burning in a variety of vegetation and terrain. Irradiance from two crown fires burning in lodgepole pine (Pinus contorta) peaked at 200 and $300 \mathrm{~kW} \mathrm{m-2}$ respectively with flames reaching $30 \mathrm{~m}$, convective fluxes were 15 to $20 \%$ of the peak radiative fluxes. Peak irradiance associated with fires in grasses and leaf and pine needle litter in southern longleaf pine (Pinus palustris) reached $100 \mathrm{~kW} \mathrm{m-2}$ with a mean value of 70 $\mathrm{kW} \mathrm{m}-2$ for flames nominally $2 \mathrm{~m}$ tall, convective heating were equal to or greater than the radiative flux. Fires burning in sagebrush (Artemisia tridentata subsp. Wyomingensis) dominated ecosystems generated peak radiant energy fluxes of $132 \mathrm{~kW}$ m-2 with a mean value of $127 \mathrm{~kW} \mathrm{~m}-2$ for flames less than $3 \mathrm{~m}$ tall, peak convective heating was 20 to $70 \%$ of the radiative heating magnitudes on slopes of 10 to $30 \%$. Napier and Roopchand (1986) report an average incident radiant flux of $7.5 \mathrm{~kW} \mathrm{m-2} 159$ $\mathrm{m}$ away from LNG flames $80 \mathrm{~m}$ tall and $31 \mathrm{~m}$ in diameter. Measurements incidate that flame increases nearly monotonically with approach of the flame front and declines exponentially with its passage. Irradiance beneath crown fires peaks at $300 \mathrm{~kW} \mathrm{m-2,} \mathrm{peak} \mathrm{irradiance} \mathrm{associated} \mathrm{with} \mathrm{fires} \mathrm{in} \mathrm{surface}$ fuels reaches $100 \mathrm{~kW} \mathrm{m-2}$ with a mean value of $70 \mathrm{~kW} \mathrm{~m}-2$; the peak for fires burning in shrub fuels was $132 \mathrm{~kW} \mathrm{m-2}$ with a mean value of $127 \mathrm{~kW}$ m-2.

Recent measurements of convective energy transport have shown that instantaneous peak convective energy fluxes inside flames may significantly exceed the radiant fluxes although convective heating based on 2 s moving averages are nominally $70 \%$ of similarly averaged radiant heating values (Frankman et al. 2012b). Measurements of flame geometry ahead of a spreading fire front suggest as slope exceeds nominally $30 \%$ flames begin to attach to the surface and high temperature gases are convected along the slope (Viegas 2004). Crown fires in lodgepole pine (Pinus contorta) resulted in 2 second averaged convective fluxes from 15 to $20 \%$ of the peak radiative fluxes. However, fires in surface fuels characteristic of a southern longleaf pine (Pinus palustris) ecosystem showed convective heating equal to or greater than the radiative flux. Fires burning in sagebrush (Artemisia tridentata subsp. Wyomingensis) or similar shrub dominated ecosystems produced peak convective heating 20 to $70 \%$ of the radiative heating magnitudes.

\section{Results}

It is commonly believed that radiant energy decays as the inverse of the square of the distance away from the source. This is based on energy transport theory and ideally holds true. While it is somewhat arbitrary, the data collected as part of this study were grouped according to the vegetation and fire type (i.e. grass, brush, moderate intensity crown and high intensity crown). Measurements of total incident heating are plotted below and compared to the ideal decay model (Figure 1). Clearly the correlation is not entirely accurate. It appears that "real" wildland flames do not necessarily represent ideal flame models. Logically departure from theoretical flame behavior can be attributed to three primary factors: 1) absorption of energy by water vapor and carbon dioxide in the atmosphere, 2) convective energy transport away from the fire, and 3) varying temperature and emissivity of the flame. The implications from these data are that the $1 / \mathrm{r} 2$ rule (which theoretically applies to radiative heating) does not seem to apply to total energy transfer from fires suggesting that convective energy transport extends the distance over which heating from the flames occurs. In the context of firefighter safety zones, these results suggest that convective heating can be a significant contributor to energy transfer from fires. Figure 2 presents energy levels as a function of vegetation type which is intended to be a surrogate for fire intensity. The burn injury threshold of $7 \mathrm{~kW} \mathrm{m-2}$ is displayed in both graphs. Based on these groupings, the decay in intensity with distance can be simulated using a model of the form $\mathrm{q}=\mathrm{m} / \mathrm{rn}$ where $(\mathrm{q})$ is incident heating level at distance $(\mathrm{r})$ from the flame, $(\mathrm{m})$ is a constant, and the exponent (n) is 0.75 for these data. The values for $(\mathrm{m})$ scale nominally with the observed peak total heating values measured in each grouping, the exponents (n) were held constant. The largest discrepancy between this model and the data occurs for the moderate intensity crown fire data. These data are based on measurements over a range of topographical and vegetation types. Also the arbitrary nature of the 
grouping could alter the results. However, there is some intuitive comfort derived from the correlation between peak total heating values and the constant multiplier values.

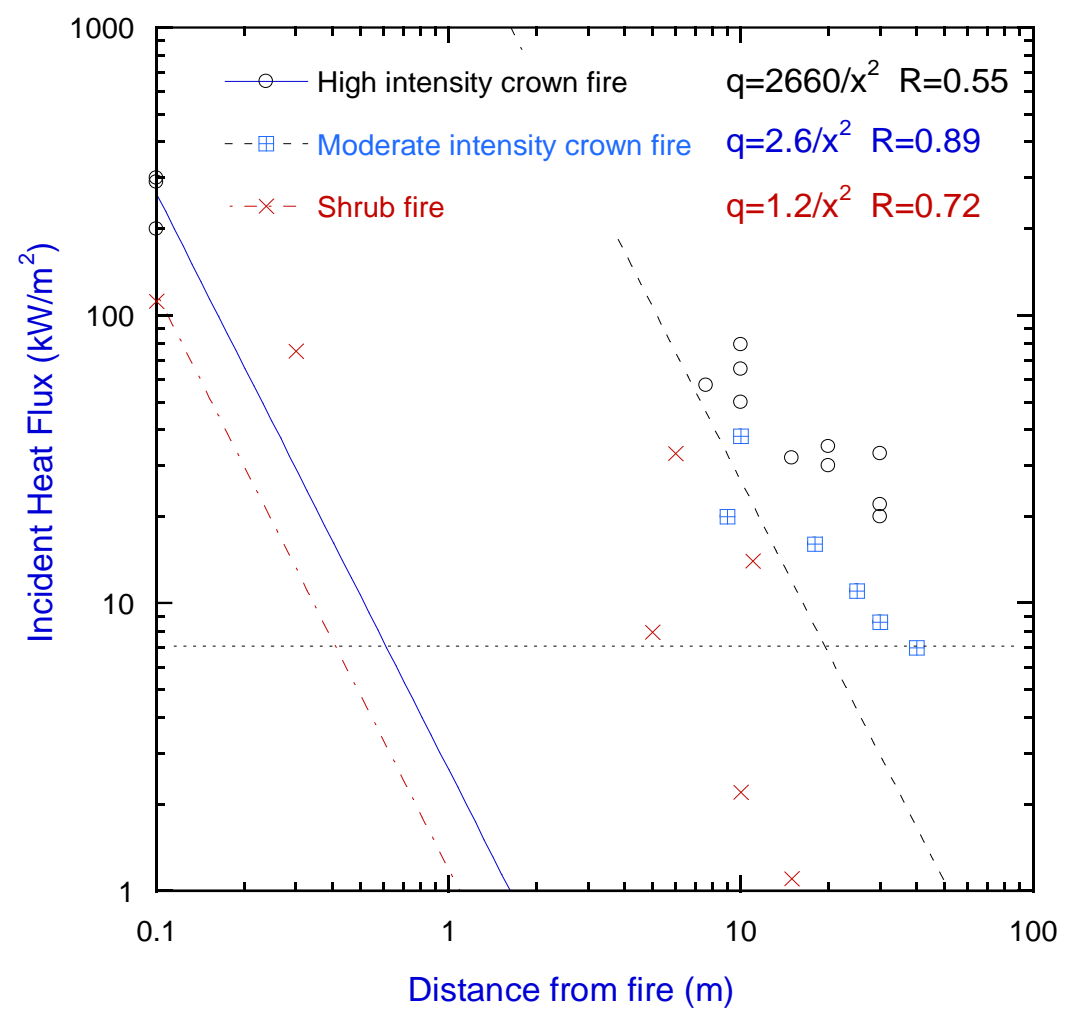

Figure 1-Comparison of measurements to inverse squared law.

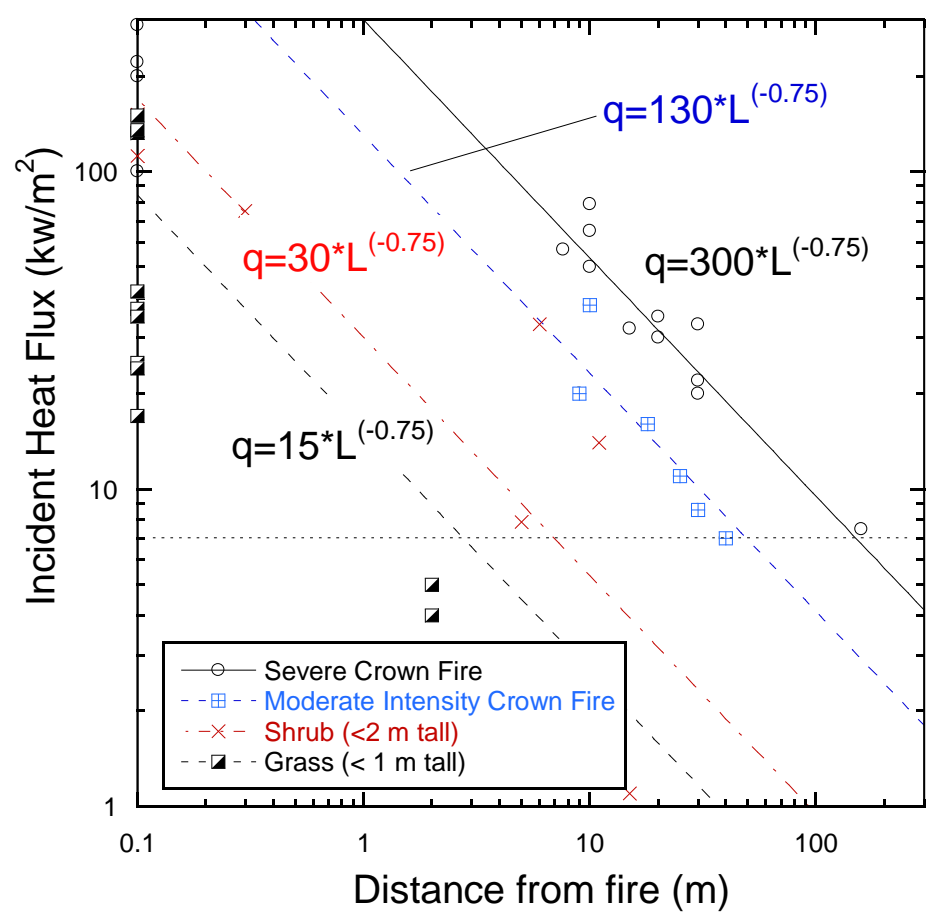

Figure 2-- Exponent based models for energy decay with distance for wildland fires. 
Four heating regimes are identified for these data. The lowest being that associated with fire in grass vegetation (nominally less than $1 \mathrm{~m}$ tall). The measurements are best fit by a line defined as q=15/L0.75 where $\mathrm{L}$ is the distance between the receptor and the fire. The next highest heating level is associated with shrub vegetation similar to sage brush. Nominally 1 to $2 \mathrm{~m}$ tall. The best fit for heating level as function of distance from flame is $q=30 /$ L0.75. For taller shrubs (e.g. gamble oak or other shrubs 2 to $5 \mathrm{~m}$ tall) or low intensity crown fires the fit is $\mathrm{q}=130 / \mathrm{L} 0.75$. Finally when considering the most intense fires such as those typically associated with forest crowns the best fit is $q=300 / \mathrm{L} 0.75$. The horizontal dashed line represents the level at which second degree burn injury will occur in roughly 30 to 60 seconds. Logically the point at which the best fit for energy distribution crosses the burn injury limit would represent the minimum distance required from a fire in the particular vegetation type to prevent injury. Based on these data a rule for SSD that is dependent only on vegetation type is proposed. The rule is based on extrapolating vertically downward from the intersection of the line corresponding to each fire (or vegetation) type and the burn injury limit of $7 \mathrm{~kW} \mathrm{~m}-2$ to the horizontal axis. The intersection with the horizontal axis would be the distance from the fire necessary to maintain an exposure below the burn injury limit. Thus for the highest intensity crown fires nominally $105 \mathrm{~m}$ is required, for moderate intensity crown fires or fire in 2 to $5 \mathrm{~m}$ tall shrubs the minimum distance is 60 $\mathrm{m}$, for fires in 1 to $2 \mathrm{~m}$ tall shrubs or tall grass the minimum distance is $8 \mathrm{~m}$ and for fires in grass less than $1 \mathrm{~m}$ tall the minimum separation distance is $3 \mathrm{~m}$. This approach includes wind and slope implicitly in the data set. There is no direct accounting for steep slopes or strong winds. Additionally only a few data points were collected in steep terrain or windy conditions, thus this empirical model does not have a strong slope or wind component.

Butler (2014) evaluates safety zones for selected firefighter entrapments over the past 70 years in the United States. Figure 3 compares entrapment data presented in that study as well as a few other entrapments in the context of the empirical SSD model for the entrapments. Table 1 summarizes the entrapment incident details. The data indicate that for all but two fire incidents the empirical model suggests a larger SSD is required. In most cases the difference between the actual SSD and the suggested SSD is significant (for example consider the Mann Gulch, Inaja, Dude, Thirtymile, Cramer, and Yarnell Hill fires). The suggested SSD is significantly larger than the actual SSD. All of these are associated with fatal entrapments. However the Blackwater, Butte, South Canyon-II deployment are fires where firefighters deployed fire shelters, or in the case of the Blackwater fire took evasive action and survived, albeit in some cases very uncomfortably. The Butte fire and South Canyon-II entrapments had actual SSD greater than that specified from the empirical model. In the Butte fire incident, firefighters deployed aluminium fire shelters in a prepared safety zone. They had to move from one side of the clearing to the other as the fire burned around the area. In the South Canyon-II entrapment, 8 firefighters deployed on a rocky ridge nominally $160 \mathrm{~m}$ from the primary vegetation (Gambel Oak). At no time did they feel threatened in their shelters and some indicated they believe they would have been safe without the shelters. These two incidents suggest that the empirical model seems to underpredict the minimum distance needed.

The empirical model is attractive from the standpoint that it is simple to memorize and apply, it does not require that the firefighter visualize the fire behaviour, and can be applied quickly. But it does not consider slope or wind both of which are considered shortcomings in the present safety zone rule applied in the United States. These shortcomings might be the reason why there are some fires where the proposed SSD was lower than the actual SSD (i.e. Butte, and South Canyon-II). 
Table 1-Fire incident details

\begin{tabular}{|c|c|c|c|c|c|c|c|c|}
\hline Incident & Fatalities & Injuries & Vegetation & $\begin{array}{c}\text { Vegetation } \\
\text { Ht (m) }\end{array}$ & $\begin{array}{l}\text { Flame } \\
\text { Ht (m) }\end{array}$ & $\begin{array}{c}\text { Actual } \\
\text { SSD (m) }\end{array}$ & $\begin{array}{c}\text { Actual } \\
\text { SSD/Flame } \\
\text { Ht }\end{array}$ & $\begin{array}{c}\text { Empirical } \\
\text { SSD/Flame } \\
\text { Ht }\end{array}$ \\
\hline Blackwater & & 36 & Timber & 25 & 80 & 30 & 0.37 & 1.3 \\
\hline Mann Gulch & 13 & 1 & Timber & 20 & 10 & 13 & 1.3 & 10 \\
\hline Inaja & 11 & & Shrub & 8 & 12 & 5 & 0.42 & 3.3 \\
\hline Loop & 10 & 12 & Brush & 6 & 10 & 15 & 1.5 & 5.0 \\
\hline $\begin{array}{l}\text { Battlement } \\
\text { Mesa }\end{array}$ & 3 & 1 & Brush & 5 & 14 & 5 & 0.36 & 3.6 \\
\hline Butte & & 73 & Timber & 30 & 70 & 125 & 1.8 & 1.4 \\
\hline Dude & 6 & & Timber & 15 & 50 & 5 & 0.10 & 2.0 \\
\hline So Can-I & 14 & & Brush & 5 & 29 & 2 & 0.069 & 1.7 \\
\hline So Can-II & & 8 & Brush & 5 & 29 & 160 & 5.5 & 1.7 \\
\hline 30-mile & 4 & 12 & Timber & 25 & 50 & 5 & 0.10 & 2.0 \\
\hline Cramer & 2 & & Timber & 20 & 30 & 3 & 0.10 & 3.3 \\
\hline Esperanza & 5 & & Brush & 5 & 20 & 10 & 0.50 & 2.5 \\
\hline Yarnell Hill & 19 & & Brush & 5 & 30 & 5 & 0.17 & 1.7 \\
\hline
\end{tabular}

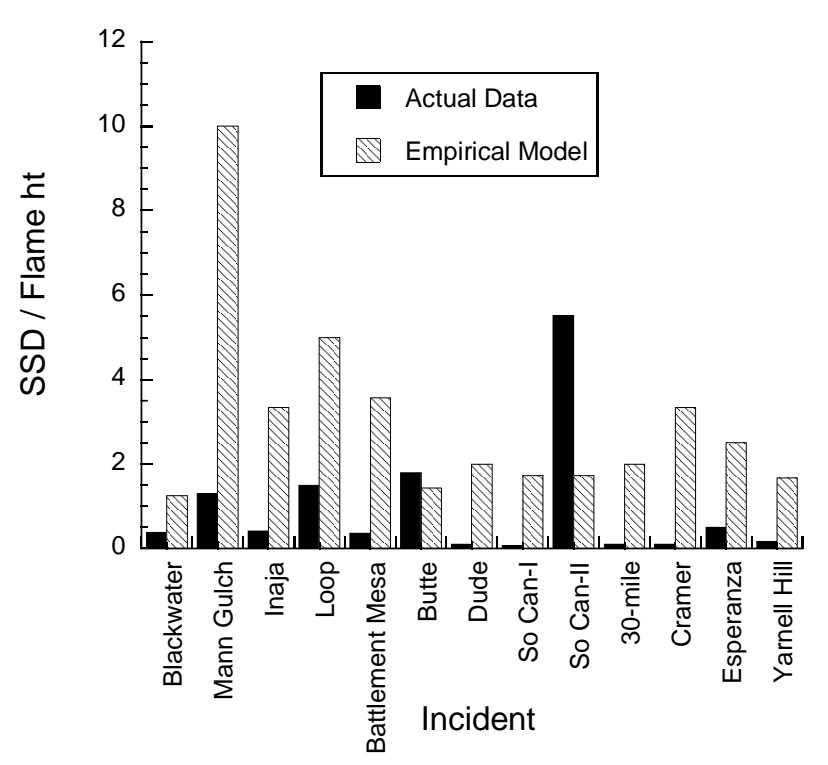

Figure 3-Comparison of actual entrapments and empirical safety zone SSD model.

\section{Conclusions}

Many questions remain regarding how energy is generated and released from wildland flames and the implications of energy distribution on safety zone effectiveness. It is only recently that measurements have identified the range of heating magnitudes that can be expected from wildland flames. The prediction of fire behaviour, especially during dynamic fire operations can be very difficult even with access to sophisticated computer models and hardware. Current studies suggest that heating levels of 6 to $7 \mathrm{~kW} \mathrm{m-2} \mathrm{generally} \mathrm{represent} \mathrm{burn} \mathrm{injury} \mathrm{limits,} \mathrm{however} \mathrm{a} \mathrm{more} \mathrm{appropriate} \mathrm{metric} \mathrm{is} \mathrm{thermal}$ dosage unit that includes both heating magnitude and exposure time (Butler 2014). Comparison between a selected set of fire entrapments and the empirical model derived from the data presented here suggests that the empirical model suggests SSD on the order of the current guideline based on earlier work (Butler and Cohen 1998). Intuition, professional observations, and the few experimental measurements that have been reported indicate that when fires are located on or adjacent to slopes or 
ridges or are exposed to winds convective energy transfer may reach distances equal to 2 to 3 or more flame lengths ahead of the fire front (Frankman et al. 2012a). This implies that the empirical model may underestimate SSD in some situations. This conclusion is supported by the comparison to fire entrapments. Recent measurements suggest that in the context of wildland firefighter safety zones on slopes an accurate accounting of energy transport requires consideration of both convective and radiative heating. The inclusion of convective heating implies that slope steepness, ambient wind, and safety zone geometrical location relative to terrain slope are all relevant.

\section{Acknowledgements}

This work could not have been accomplished without the financial support provided by the Joint Fire Sciences Program, as well as support from fire managers in the Bureau of Land Management and the National Park Service when we were deploying sensors in and around fires. We also acknowledge the enthusiastic support from many fire crews, as well as forest service district, and forest staff.

\section{References}

Albini, FA (1986) Wildland fire spread by radiation-- a model including fuel cooling by natural convection. Combustion Science \& Technology 45, 101-113.

Anderson, WR, Catchpole, EA, Butler, BW (2010) Convective heat transfer in fire spread through fine fuel beds. International Journal of Wildland Fire 19, 284-298.

Butler, BW (1993) Experimental measurements of radiant heat fluxes from simulated wildfire flames. In '12th International Conference of Fire and Forest Meteorology, Oct. 26-28, 1993. Jekyll Island, Georgia', Oct. 26-28, 1993. (Eds JM Saveland, J Cohen) Volume 1 pp. 104-111. (Society of American Foresters, Bethesda, MD:

Butler, BW (2014) Wildland firefighter safety zones: a review of past science and summary of future needs. International Journal of Wildland Fire 23, 295-308.

Butler, BW, Cohen, J, Latham, DJ, Schuette, RD, Sopko, P, Shannon, KS, Jimenez, D, Bradshaw, LS (2004) Measurements of radiant emissive power and temperatures in crown fires. Canadian Journal of Forest Research 34, 1577-1587.

Butler, BW, Cohen, JD (1998) Firefighter safety zones: a theoretical model based on radiative heating. International Journal of Wildland Fire 8, 73-77.

Frankman, D, Webb, BW, Butler, BW, Jimenez, D, Forthofer, JM, Sopko, P, Shannon, KS, Hiers, JK, Ottmar, RD (2012a) Measurements of convective and radiative heating in wildland fires. International Journal of Wildland Fire 22, 157-167.

Frankman, D, Webb, BW, Butler, BW, Jimenez, D, Harrington, M (2012b) The impact of sampling rate on interpretation of the temporal characteristics of radiative and convective heating in wildland flames. International Journal of Wildland Fire

King, AR (1961) Compensating radiometer. British Journal of Applied Physics 633.

Morandini, F, Silvani, X, Rossi, L, Santoni, P-A, Simeoni, A, Balbi, J-H, Louis Rossi, J, Marcelli, T (2006) Fire spread experiment across Mediterranean shrub: Influence of wind on flame front properties. Fire Safety Journal 41, 229-235.

Napier, DH, Roopchand, DR (1986) An approach to hazard analysis of LNG spills. Journal of Occupational Accidents 7, 251-272.

National Wildfire Coodinating Group, NIFC, 1997. Historical Wildland Firefighter Fatalities 19101996. National Interagency Fire Center, Boise, ID. PMS 822 NFES 1849: 42.

National Wildfire Coodinating Group, NIFC, 2004. NWCG Fireline Handbook. National Wildfire Coordinating Group, Boise, ID. NWCG Handbook 3, PMS 410-1, NFES 0065:

Packham, D, Pompe, A (1971) Radiation temperatures of forest fires. Australian Forest Research 5, 1 8. 
Rossi, JL, Simeoni, A, Moretti, B, Leroy-Cancellieri, V (2011) An analytical model based on radiative heating for the determination of safety distances for wildland fires. Fire Safety Journal 46, 520-527.

Silvani, X, Morandini, F (2009) Fire spread experiments in the field: Temperature and heat fluxes measurements. Fire Safety Journal 44, 279-285.

Viegas, DX (2004) On the existence of a steady state regime for slope and wind driven fires. International Journal of Wildland Fire 13, 101-117.

Viskanta, R (2008) Overview of some radiative transfer issues in simulation of unwanted fires. International Journal of Thermal Sciences 47, 1563-1570.

Yedinak, KM, Cohen, JD, Forthofer, JM, Finney, MA (2010) An examination of flame shape related to convection heat transfer in deep-fuel beds. International Journal of Wildland Fire 19, 171-178.

Yedinak, KM, Forthofer, JM, Cohen, JD, Finney, MA (2006) Analysis of the profile of an open flame from a vertical fuel source. Forest Ecology and Management 234, S89-S89.

Zarate, L, Arnaldos, J, Casal, J (2008) Establishing safety distances for wildland fires. Fire Safety Journal 43, 565-575. 